\title{
Pengaruh Struktur Modal, Current Ratio Dan Laba Perlembar Saham Terhadap Kinerja Perusahaan (Studi Empiris Pada Perusahaan Manufaktur Yang Terdaftar Di Bursa Efek Indonesia (Bei) Tahun 2013-2017)
}

\author{
Berta Agus Petra, Yosi Puspita Sari, Muhammad Pondrinal, Dicky Agung Alfino \\ Universitas Putra Indonesia YPTK Padang, Indonesia \\ E-mail : agusberta@upiyptk.ac.id
}

\begin{abstract}
Abstrak
Penelitian ini bertujuan untuk mengetahui seberapa besar pengaruh Stuktur Modal, Current Ratio dan Laba Perlembar Saham terhadap Kinerja Perusahaan pada perusahaan sektor manufaktur yang terdaftar di Bursa Efek Indonesia (BEI) periode 2013-2017. Penelitian ini menggunakan populasi di perusahaan manufaktur sektor industri konsumsi dan industri lainnya yang terdaftar di Bursa Efek Indonesia (BEI) periode 20132017 dengan menggunakan 38 sampel perusahaan.teknik pengambilan sampel pada penelitian ini menggunakan metode purposive sampling. Dalam penelitian ini menggunakanan analisis regresi linear berganda. Hasil penelitian ini menunjukan bahwasanya Struktur modal (DAR) tidak berpengaruh secara signifikan terhadap kinerja perusahaan pada perusahaan sektor manufaktur yang terdaftar di Bursa Efek Indonesia (BEI) periode 2013-2017 (ROA). Current ratio (CR) berpengaruh secara signifikan terhadap kinerja perusahaan pada perusahaan sektor manufaktur yang terdaftar di Bursa Efek Indonesia (BEI) periode 2013-2017 (ROA). Laba perlembar saham (EPS) berpengaruh secara signifikan terhadap kinerja perusahaan pada perusahaan sektor manufaktur yang terdaftar di BEI periode 2013-2017 (ROA). Struktur modal (DAR), Current ratio (CR), Laba perlembar saham (EPS) berpengaruh secara simultan terhadap kinerja perusahaan pada perusahaan sektor manufaktur yang terdaftar di Bursa Efek Indonesia (BEI) periode 2013-2017 (ROA) yang berarti berpengaruh signifikan secara simultan terhadap kinerja perusahaan pada perusahaan sektor manufaktur yang terdaftar di Bursa Efek Indonesia (BEI) periode 2013-2017.
\end{abstract}

Kata Kunci: Kinerja Perusahaan, Struktur Modal, Current Ratio dan Laba Perlembar Saham

\section{Pendahuluan}

Perekonomian yang terjadi saat ini di imbangi dengan adanya persaingan yang begitu ketat dan kompeten, hal ini menuntut perusahaan untuk mengembangkan berbagai strategi agar perusahaan dapat bersaing dan berkembang baik itu di tingkat nasional maupun di tingkat internasional.Pada umumnya, perusahaan didirikan bertujuan untuk memakmurkan pemilik perusahaan atau pemegang saham. Tujuan ini dapat diwujudkan dengan memaksimalkan nilai suatu perusahaan dengan asumsi bahwa pemilik perusahaan atau pemegang saham akan makmur jika penghasilan suatu perusahaan meningkat.

Meningkatnya suatu penghasilan pada perusahaan dapat dilihat dari semakin meningkatnya harga saham yang berarti juga nilai perusahaan akan meningkat. Untuk menghindari kemungkinan-kemungkinan yang dapat menjadi pemicu menurunnya kinerja perusahaan, diperlukan penerapan sistem yang baik, pengawasan yang efektif, dan pengambilan keputusan yang tepat dalam meningkatkan kualitas kerja suatu perusahaan.Bagi manajemen diharapkan mampu mengambil tindakan atau keputusan yang tepat agar perusahaan tetap dan menghasilkan laba bagi perusahaan, sehingga perusahaan menjadi sangat baik dan maksimal dan perusahaan akan di pandang baik oleh calon investor.

Industri manufaktur memberikan kontribusi terbesar terhadap nilai ekspor nasional.Hal ini menandakan produk lokal mampu bersaing di pasar global. Pada tahun I/2018 sumbangsih ekspor dari industri manufaktur hingga 71,59\% dari total ekspor nasional yang mencapai USD88,02 miliar. Jumlah ekspor produk industri manufaktur kita sebesar USD63,01 miliar atau naik 5,35\% 
dibanding periode yang sama tahun lalu di angka USD59,81 miliar. Pemerintah saat ini fokus untuk meningkatkan nilai ekspor guna mengatasi defisit neraca perdagangan.Peningkatan ekspor cukup penting dalam mengerek penguatan Rupiah. (www.sindonews.2018)

Terdapat beberapa faktor yang mempengaruhi kinerja suatu perusahaan, didalam penelitian ini ada beberapa faktor-faktor yang mempengaruhinya seperti : struktur modal, current ratio, dan laba perlembar saham (earning per share). Faktor pertama struktur modal, struktur modal merupakan masalah yang penting bagi suatu perusahaan karena baik atau buruk nya struktul modal akan mempunyai efek langsung terhadap posisi finansial perusahaan yang pada akhirnya akan mempengaruhi nilai perusahaan, suatu perusahaan jika melakukan kesalahan dalam menentukan struktuk modal akan mempunyai dampak yang luas bagi perusahaan terutama apabila perusahaan terlalu besar dalam menggunakan hutang, maka beban tetap yang harus ditanggung perusahaan semakin besar. Hal itu juga berarti akan meningkatkan resiko finansial yaitu resiko saat perusahaan tidak dapat mebayar beban bunga atau angsuran hutangnya.

Menurut Hermuningsih (2013) penggunaan hutang sebagai sumber pendanaan perusahaan memiliki keuntungan dan kerugian.Keuntungan penggunaan hutang di peroleh dari pajak (bunga hutang) dan disiplin manajer (kewajiban membayar hutang berhubungan dengan timbulnya biaya keagenan dan biaya kepailitan.Pemodal selalu berusaha mengurangi risiko yang akan ditanggungnya. Risiko terdiri atas risiko tak sistematis yang disebabkan oleh fluktuasi semua perusahaan yang sedang beroperasi dan risiko sistematis yaitu risiko yang melekat di dalam saham. Perhitungan rasio saat ini yang terdapat dalam analisis laporan keuangan, menganalisis laporan keuangan, sering digunakan untuk menganalisis dan menilai kinerja keuangan perusahaan merupakan cara yang sederhana dengan memberikan hasil pengukuran yang relatif.

Faktor kedua current ratio (CR), dimana pengukuran current ratio (CR) ini disarkan pada perbandingan aktiva lancar dengan hutang jangka pendek yang harus dibayarkan oleh perusahaan. Tingginya hasil (CR) yang didapat akan semakin baik bagi kreditur karana perusahaan yang dianggap mampu untuk dapat melunasi segala kewajibannya, namun (CR) yang tinggi bagi pemegang saham akan kurang mengguntungkan bagi perusahaan dan (CR) yang rendah juga relatif lebih riskan, namun menentukan bahwa manajemen menggunakan aktiva lancar nya dengan efektive untuk menigkatkan keuntungan.

Apabila tingkat (CR) tinggi, maka perusahaan dikatan mampu untuk mebayar segala kewajiban jangka pendek nya kepada kreditur. Namun (CR) yang tinggi juga tidak selalu baik karena akan menunjukan bahwa akan terdapat aktiva lancar yang berlebih yang tidak digunakan secara efektif sehingga dapat menyebabkan berkurang nya keuntungan atau tingkat profitabilitas.Menurut penelitain Maladijan (2014) menunjukan bahwa (CR) memiliki pengaruh negatif signifikan terhadap devidend payout ratio. Pada umumnya current ratio digunakan perusahaan untuk mengukur kemampuan manajemen dalam membayar segala hutang jangka pendeknya yang telah jatuh tempo.

Faktor ketiga Earning per share (EPS) atau laba per lembar saham yang merupakan hal menarik bagi para investor, dimana (EPS) merupakan tingkat keuntungan yang diperoleh pemegang saham setiap lembar saham yang dimilikinya. (EPS) salah satu cara untuk mengukur keberhasilan pihak manajemen dalam mencapai keuntungan bagi para pemilik perusahaan.Harga suatu saham mencerminkan juga nilai dari suatu perusahaan, perusahaan berfluktuasi setiap tahunnya ketidak pastian harga saham sangat menyulitkan investor dalam melakukan investasi oleh karena itu investor tidak sembarangan melakukan investasi atas dana yang dimilikinya.

Menurut penelitian Rahmanto dan Shaferi (2014) tingginya nilai (EPS) akan mengurangi ketidakpastian bagi investor sehingga akan menurunkan tingkat underpricing, yang berarti kemungkinan investor mendapatkan initial return pada saat penawaran perdana akan semakin rendah.

Penelitian yang dilakukan oleh Dwidjaja (2017) yang berjudul faktor-faktor yang mempengaruhi struktur modal terhadap kinerja perusahaan yang terdaftar di Bursa Efek Indonesia periode 2011-2015. Hasil penelitian ini menunjukan bahwa variable tangibility memiliki pengaruh yang positif dan signifikan terhadap struktur modal.Sedangkan Redawati dkk (2014) yang berjudul pengaruh struktur modal terhadap kinerja perusahaan.Hasil penelitian ini menunjukan bahwa DAR berpengaruh positif tetapi tidak signifikan terhadap ROA dan negatif tetapi tidak 
signifikan terhadap ROE sementara DER negatif tetapi tidak signifikan terhadap ROA dan positif tetapi tidak signifikan terhadap ROE.

Wang dan Zhu (2014) Melakukan penelitian di perusahaan yang terdaftar di Cina, yang berjudul the impact of capital structure on corporate performance based on panel threshold model. Hasil penelitian ini menunjukan bahwa ada korelasi positif yang lemah antara manajemen lingkungan dan kinerja perusahaan yang berarti manajemen lingkungan dapat miningkatkan kinerja perusahaan, ada efek rezim yang signifikan antara struktur modal dan kinerja perusahaan yang mengandalkan perusahaan.

Penelitian ini mengacu kepada peneliti Dwidjaja (2017) Dimana peneliti ini melakukan penelitian di perusahaan Bursa Efek Indonesia periode 2011-2015.Penelitan ini bertujuan untuk mengidentifikasi faktor-faktor yang mempengaruhi struktur modal dan pengaruhnya terhadap kinerja perusahaan. Variabel yang digunakan yaitu debt ratio, return on asset, tanggibility, size, growth dan liquidity. Penelitian ini menggunakan pendekatan kuantitatif dengan model analisis two stages least square (TSLS). Penelitian ini menggunakan target penelitian penelitian seluruh sektor perusahaan yang terdaftar di Bursa Efek Indonesia pada periode 2011-2015. Jumlah observasi dalam penelitian ini adalah 1370 observasi.Penelitian ini menunjukan bahwa variabel tangibility memiliki pengaruh yang positif dan signifikan terhadap struktur modal.Sedangkan variabel size, growth, dan liquidity memiliki pengaruh yang negatif dan signifikan.

\section{Tinjauan Literatur}

\subsection{Kinerja Perusahaan}

Simanjuntak (2011 : 3) menjelaskan pengertian kinerja perusahaan adalah agresi atau akumulasi kinerja semua unit-unit organisasi, yang sama dengan penjumlahan kinerja semua orang atau individu yang bekerja di perusahaan. Kinerja perusahaan dalam penelitian ini di rumuskan sebagai berikut:

$$
\mathrm{ROA}=\frac{\text { laba bersih setelah pajak............ (1) }}{\text { total asset }}
$$

\subsection{Struktur Modal}

Struktur modal Fahmi (2015 : 193) menyatakan bahwa struktur modal adalah gambaran dari bentuk proporsi financial perusahaan yaitu antara modal yang dimiliki yang bersumber dari hutang jangka panjang dan modal sendiri yang menjadi sumber pembiayaan suatu perusahaan. Struktur modal dalam penelitian ini di rumuskan sebagai berikut:

$$
\mathrm{DAR}=\frac{\text { total hutang } \ldots \ldots \ldots \ldots \ldots \ldots \ldots \ldots(2)}{\text { total aset }}
$$

\subsection{Current Ratio}

Current ratio Kasmir (2016 : 34) menerangkan bahwa rasio lancar atau current ratio merupakan rasio untuk mengukur kemampuan perusahaan dalam membayar kewajiban jangka pendek atau utang yang segera jatuh tempo pada saat ditagih secara keseluruhan. Current ratio dalam peneltian ini di rumuskan sebagai berikut:

$$
\text { Rasio Lancar }=\frac{\text { aktiva lancar } \ldots \ldots \ldots \ldots \ldots \ldots \ldots \text { (3) }}{\text { utang lancar }}
$$




\subsection{Laba Perlembar Saham}

Fahmi (2012 : 96) mendefinisikan earning per share sebagai laba perlembar saham adalah bentuk pemberian keuntungan yang diberikan kepada para pemegang saham dari setiap lembar saham yang dimiliki. Laba perlembar saham dalam penelitian ini di rumuskan sebagai berikut:

EPS $=$ laba bersih setelah pajak ......................... (4)

Jumlah saham yang beredar

\subsection{Kerangka Pikir}

Berdasarkan uraian-uraian yang telah dikemukakan pada pembahasan sebelumnya, sebagai dasar untuk merumuskan hipotesis, dapat digambarkan kerangka penelitian yang tersaji dibawah ini :

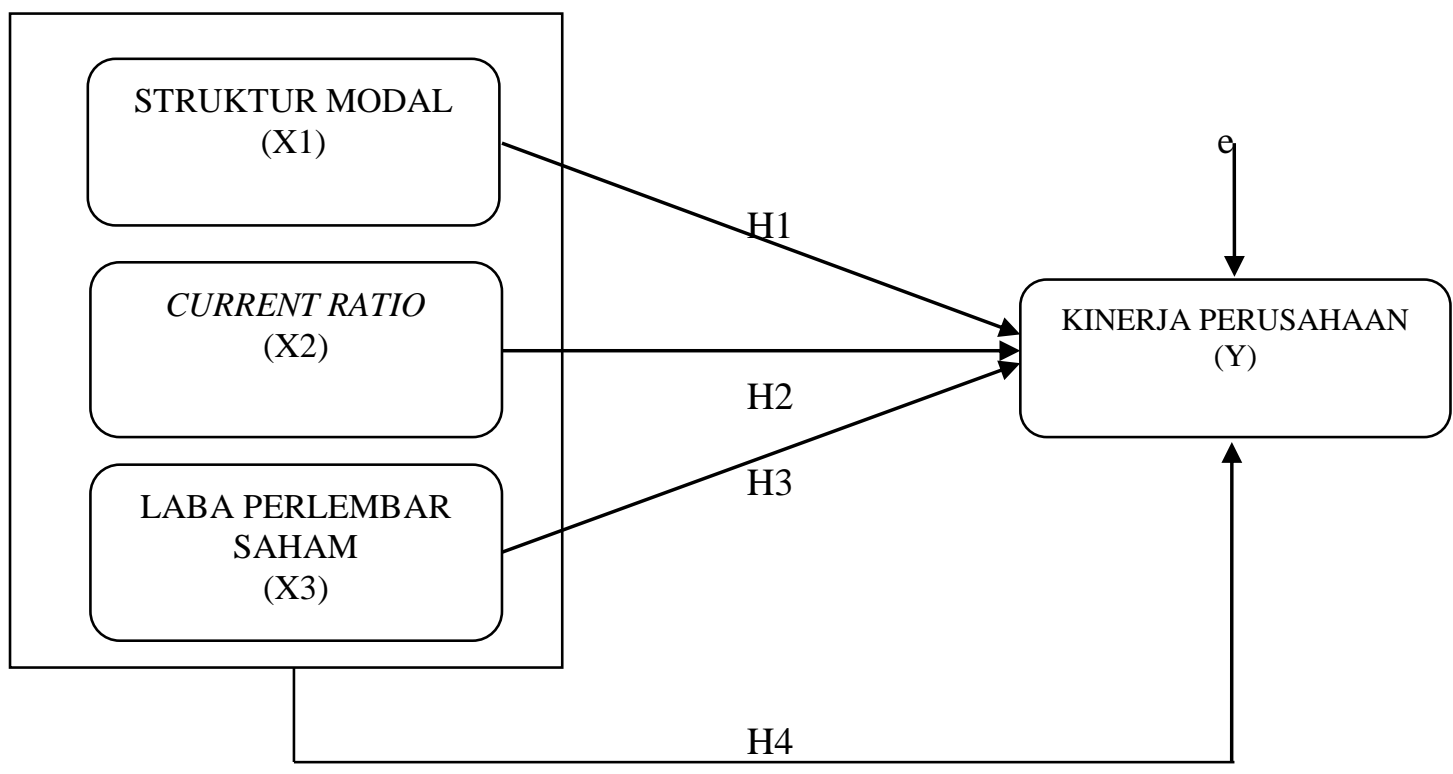

Gambar 1. Kerangka Pemikiran

\section{Metodologi Penelitian}

\subsection{Analisis Regresi Linear Berganda}

Analisis regresi digunakan untuk melihat pengaruh variabel independen struktur modal, current ratio, laba perlembar saham, secara simultan terhadap variabel dependen : kinerja perusahaan dengan asumsi variabel independen lain dianggap konstan. Dapat diformulasikan dalam bentuk persamaan berikut ini:

$$
\mathrm{Y}=\beta_{0}+\beta_{1} \mathrm{SM}+\beta_{2} \mathrm{CR}+\beta_{3} \mathrm{EPS}+\mathrm{e}
$$

\subsection{Pengujian Hipotesis}

Pengujian ini dilakukan untuk mengetahui pengaruh variabel independen, yaitu struktur modal, current ratio, laba perlembar saham terhadap variabel dependen yaitu kinerja perusahaaan.

\subsubsection{Uji Statistik t (Uji Signifikan Parsial)}

Uji t digunakan untuk menguji pengaruh independent variable secara parsial terhadap variable dependent. Pengujian ini dilakukan dengan ketentuan:

1. Apabila probability thitung $<0,05$, maka Ho ditolak dan Ha diterima

2. Apabila probability thitung $>0,05$, maka Ho diterima dan Ha ditolak 
Berdasarkan table, menunjukkan pengaruh variable Struktur Modal (SM), Current Ratio(CR), Laba Perlembar Saham (EPS) dapat diuji sebagai berikut:

\subsubsection{Uji Statistik $f$}

Merupakan alat yang digunakan untuk menguji apakah variabel independen berpengaruh secara bersama-sama atau simultan terhadap variabel dependennya. Adapun kriteria pengambilan keputusan sebagai berikut:

Jika probabilitas $<0,05$ maka hipotesis diterima

Jika probabilitas $>0,05$ maka hipotesis ditolak

\subsubsection{Koefisien Determinasi}

Koefisien determinasi $\left(R^{2}\right)$ adalah angka yang menyatakan atau digunakan untuk mengetahui kontribusi atau sumbangan yang diberikan oleh sebuah variabel bebas atau lebih terhadap variabel terikat. Nilai koefisien determinasi adalah antara nol dan satu. Nilai $R_{2}$ yang kecil berarti kemampuan variabel-variabel independen dalam menjelaskan variasi variabel dependen amat terbatas. Nilai yang mendekati satu berarti variabel-variabel independen hampir memberikan semua informasi yang dibutuhkan untuk memprediksi variasivariabel dependen. Kelemahan mendasar penggunaan koefisien determinasi adalah bias terhadap jumlah variabel independen yang dimasukkan ke dalam model.

\section{Hasil dan Diskusi}

\subsection{Analisis Regresi Linear Berganda}

Tabel 1. Hasil Regresi Linear Berganda

\begin{tabular}{ccccc}
\hline \hline Variable & Coefficient & Std. Error & t-Statistic & Prob. \\
\hline \hline KP & 1.613628 & 0.166056 & 9.717354 & 0.0000 \\
SM & 1.087425 & 0.033014 & 32.93801 & 0.0000 \\
CR & 0.125663 & 0.005604 & 22.42202 & 0.0000 \\
EPS & 0.005600 & 0.033870 & 0.165335 & 0.8689 \\
\hline \hline
\end{tabular}

Data pengolahan Eviews 9 didapatkan persamaan regresi linear berganda sebagai berikut :

\section{$Y=-3,725000+1,087425 S M+0,125663 C R+0,005600 E P S+e$}

Interpretasi atau penjelasan dari persamaan regresi diatas adalah sebagai berikut :

1. Nilai konstansta $(\alpha)$ adalah $-3,725000$ artinya jika struktur modal $\left(X_{1}\right)$,current ratio $\left(X_{2}\right)$, laba perlembar saham/EPS $\left(\mathrm{X}_{3}\right)$ dan nilainya adalah 0 maka kinerja perusahaan $(\mathrm{Y})$ nilainya adalah menurun $-3,725000$.

2. Nilai koefisien regresi variabel struktur modal $\left(\mathrm{X}_{1}\right)$ bernilai negatif sebesar 1,087425 artinya jika struktur modalmeningkat sebesar satu (1) satuan, maka kinerja perusahaan menurun sebesar 1,087425 dengan asumsi variabel independen lain bernilai 0 atau diabaikan.

3. Nilai koefisien regresi variabel current ratio $\left(X_{2}\right)$ bernilai positifsebesar 0,1256631 artinya jika current ratio meningkat sebesar satu (1) satuan, maka kinerja perushaaan akan naiksebesar 0,125663dengan asumsi variabel independen lain bernilai 0 atau diabaikan.

4. Nilai koefisien regresi variabel laba perlembar saham / EPS $\left(\mathrm{X}_{3}\right)$ bernilai positif sebesar 0,005600 artinya jika meningkat sebesar satu (1) satuan, maka kinerja perusahaan akan meningkat sebesar 0,005600 dengan asumsi variabel independen lain bernilai 0 atau diabaikan. 


\subsection{Uji Model \\ 4.2.1 Uji Koefisien Determinasi $\left(\mathbf{R}^{2}\right)$}

Kelemahan mendasar penggunaan koefisien determinasi adalah bias terhadap jumlah variabel independen yang dimasukkan ke dalam model. Oleh karena itu, dianjurkan untuk menggunakan Adjusted R-Square $\left(\mathrm{R}^{2}\right)$ pada saat mengevaluasi model regresi terbaik.dapat dilihat bahwa angka koefisien korelasi (R) sebesar 0,886100 . Hal ini berarti hubungan antar variabel independen dengan variabel dependen sebesar 88,61 \%. Dari angka tersebut dapat diambil kesimpulan bahwa hubungan antara variabel independen dengan variabel dependen sangat kuat.Besarnya Adjusted R-Square $\left(\mathrm{R}^{2}\right)$ sebesar 0,246989. Hasil perhitungan statistik ini berarti bahwa kemampuan variabel independen dalam menerangkan variasinya perubahan variabel dependen sebesar $24,69 \%$, sedangkan sisanya sebesar 75,31\% (100\% - 24,69\%) diterangkan oleh faktor-faktor lain diluar variabel model regresi yang dianalisis.

\subsubsection{Uji F (Simultan)}

Pengujian variabel struktur modal $\left(\mathrm{X}_{1}\right)$, current ratio $\left(\mathrm{X}_{2}\right)$, dan laba perlembar saham / EPS $\left(\mathrm{X}_{3}\right)$, terhadap kinerja perushaaan $(\mathrm{Y})$

1. Berdasarkan $\mathrm{F}_{\text {hitung }}$ dan $\mathrm{F}_{\text {tabel }}$

Pada hasil output Eviews 9.0 dapat dilihat $F_{\text {hitung }}$ sebesar17,77966. Nilai $F_{\text {hitung }}>F_{\text {tabel }}$ yaitu $-3,725000>3,08$ sehingga terdapat pengaruh. Jadi dapat disimpulkan bahwa struktur modal, current ratio dan laba perlembar saham / EPS secara simultan berpengaruh negatif terhadap kinerja perusahaan pada perusahaan Manufaktur sektor konsumsi yang terdaftar di BEI.

2. Berdasarkan angka signifikansi

Pada hasil output Eviews 9.0 dapat diketahui bahwa signifikansi sebesar 1,00000>0,05 sehingga hipotesis kelima diterima. Hipotesis kelima adalah diduga struktur modal, current ratio dan laba perlembar saham / EPS secara bersama-sama berpengaruh signifikan terhadap kinerja perusahaan.Artinya, struktur modal, current ratio dan laba perlemabr saham secara simultan berpengaruh signifikan terhadap kinerja perusahaan pada perusahaan manufaktur sektor industri yaitu industri konsumsi dan industri lainnya yang terdaftar di BEI. Dapat disimpulkan bahwa $\mathrm{H}_{0}$ diterima dan $\mathrm{H}_{\mathrm{a}}$ ditolak.

\subsubsection{Uji t (Parsial)}

Pada pengujian hipotesis, akan dilakukan pengujian signifikan koefisien regresi secara simultan (uji t), uji signifikan koefisien regresi secara simultan (uji F) dan analisis koefisien. Nilainilai statistik dari uji t, uji $\mathrm{F}$ dan koefisien determinasi $\left(R^{2}\right)$.

1. Pengujian variabel Struktur modal $\left(\mathrm{X}_{1}\right)$ Rasio Kinerja Perusahaan (Y)

a. Berdasarkan $\mathrm{t}_{\text {hitung }}$ dan $\mathrm{t}_{\text {tabel }}$

.Pada hasil output Eviews 9.0 dapat dilihat $\mathrm{t}_{\text {hitung }}$ untuk variabel struktur modal $\left(\mathrm{X}_{1}\right)$ sebesar 32,93801. Nilai $t_{\text {hitung }}>t$ tabel yaitu 32,93801> 1,666 artinya struktur modal secara parsial berpengaruh terhadap kinerja perusahaan pada perusahaan manufaktur yang terdaftar di BEI.

b. Berdasarkan angka signifikansi

Pada hasil output eviews 9.0 dapat diketahui bahwa signifikansi untuk variabel struktur modal $\left(\mathrm{X}_{1}\right)$ sebesar $0,0000<0,05$ sehingga hipotesis pertama diterima. Hipotesis pertama adalah diduga struktur modal berpengaruh signifikan terhadap kinerja perusahaan pada perusahaan manufaktur yang terdaftar di BEI.Dapat disimpulkan bahwa $\mathrm{H}_{0}$ diterima dan $\mathrm{H}_{\mathrm{a}}$ diterima. 
2. Pengujian variabel current ratio $\left(\mathrm{X}_{2}\right)$ terhadap kinerja perusahaan $(\mathrm{Y})$

a. Berdasarkan $\mathrm{t}_{\text {hitung }}$ dan $\mathrm{t}_{\text {tabel }}$

Pada hasil output eviews 9.0 dapat dilihat $\mathrm{t}$ hitung untuk variable current ratio $\left(\mathrm{X}_{2}\right)$ sebesar 22,42202 Nilai $t_{\text {hitung }}>\mathrm{t}$ tabel yaitu > 1,666 artinya Tingkat Inflasi secara parsial berpengaruh positif terhadap kinerja perusahaan pada perusahaan manufaktur yang terdaftar di BEI.

b. Berdasarkan angka signifikansi

Pada hasil output Eviews 9.0 dapat diketahui bahwa signifikansi untuk variabel Tingkat Inflasi $\left(\mathrm{X}_{2}\right)$ sebesar $0,0000<0,05$ sehingga hipotesis kedua diterima. Hipotesis kedua adalah diduga current ratio berpengaruh signifikan terhadap kinerja perusahaan pada perusahaan manufaktur yang terdaftar di BEI.Dapat disimpulkan bahwa $\mathrm{H}_{0}$ ditolak dan Ha diterima.

3. Pengujian variabel laba perlembar saham / EPS $\left(\mathrm{X}_{3}\right)$ terhadap kinerja perusahaan $(\mathrm{Y})$

a. Berdasarkan $t_{\text {hitung }}$ dan $\mathrm{t}_{\text {tabel }}$

Pada hasil output Eviews 9.0 dapat dilihat $\mathrm{t}_{\text {hitung }}$ untuk variable laba perlembar saham / EPS $\left(\mathrm{X}_{3}\right)$ sebesar 0,165335 . Nilai $\mathrm{t}_{\text {hitung }}<\mathrm{t}_{\text {tabel }}$ yaitu $0,165335<1,666$ artinya laba per lembar saham secara parsial berpengaruh positif terhadap kinerja perusahaan pada perusahaan manufaktur BEI.

b. Berdasarkan angka signifikansi

Pada hasil output Eviews 9.0 dapat diketahui bahwa signifikansi untuk variabel laba perlembar saham / EPS $\left(X_{3}\right)$ sebesar 0,8689> 0,05 sehingga hipotesis ketiga ditolak. Hipotesis ketiga adalah diduga laba perlembar saham / EPS berpengaruh signifikan terhadap kinerja perusahaan.Artinya laba perlembar saham / EPS berpengaruh signifikan terhadapkinerja perusahaan pada perusahaan manufaktur yang terdaftar di BEI. $\mathrm{H}_{0}$ ditolak dan $\mathrm{H}_{\mathrm{a}}$ ditolak.

\section{Hasil dan Pembahasan}

Berdasarkan hasil penelitian yang telah dilakukan, maka penulis dapat diinterprestasikan halhal sebagai berikut:

\section{Pengaruh Struktur Modal Terhadap Kinerja Perusahaan}

Hasil analisis menunjukkan bahwa struktur modal memiliki nilai koefisien regresi sebesar 1,087425 dan t-statistik sebesar 32,93801 dengan nilai probabilitas sebesar 0,0000 lebih kecil dari 0,05 maka dapat disimpulkan bahwa variabel struktur modal secara parsial berpengaruh dan signifikan terhadap kinerja pada perusahaan manufaktur sektor industri konsumsi dan industri lainnya yang terdaftar di BEI periode 2013-2017.

\section{Pengaruh Current Ratio terhadap Kinerja Perusahaan}

Hasil analisis menunjukkan bahwa current ratio memiliki nilai koefisien regresi sebesar 0,125663 dan t-statistik sebesar 22,42202 dengan nilai probabilitas sebesar 0,0000 lebih kecil dari 0,05 maka dapat disimpulkan bahwa variabel current ratio secara parsial berpengaruhdan signifikan terhadap kinerja pada perusahaan manufaktur sektor industri konsumsi dan industri lainnya yang terdaftar di BEI periode 2013-2017.

\section{Pengaruh Laba Perlembar Saham/ EPS terhadap Kinerja Perusahaan}

Hasil analisis menunjukkan bahwa earning per sharememiliki nilai koefisien regresi sebesar 0,005600 dan t-statistik sebesar 0,165335 dengan nilai probabilitas sebesar 0,8689lebih besar dari 0,05 maka dapat disimpulkan bahwa variabel earning per share secara tidak berpengaruh terhadap 
kinerja pada perusahaan manufaktur sektor industri konsumsi dan industri lainnya yang terdaftar di BEI periode 2013-2017.

\section{Pengaruh Struktur Modal, Current Ratio dan Laba Perlembar Saham / EPS terhadap Kinerja Perusahaan.}

Hasil analisis menunjukkan bahwayang dihasilkan dalam pengujian Sum Squared Resid bernilai sebesar 0,246989. Hasil yang diperoleh bahwa variabel struktur modal (X1), curret ratio (X2), laba perlembar saham (X3) mampu memberikan kontribusi dalam mempengaruhi kinerja perusahaan $(\mathrm{Y})$ pada perusahaan manufaktur sektor industri konsumsi dan industri lainnya yang terdaftar di BEI periode 2013-2017.

\section{Kesimpulan}

Berdasarkan pada penelitian yang dilakukan dengan pembahasan pengujian hipotesis yang berjudul Pengaruh Struktur Modal, Current Ratio, Laba Perlembar Saham / EPS terhadap Kinerja Perusahaan dengan Leverage sebagai variabel kontrol. Maka dapat diajukan beberapa kesimpulan penting yang merupakan inti jawaban dari masalah yang dibahas didalam penelitian ini, yaitu :

1. Struktur modal tidak berpengaruh secara signifikan terhadap kinerja perusahaan.

2. Current ratio berpengaruh positif dan signifikan terhadap kinerja perusahaan.

3. Laba perlembar saham / EPS berpengaruh positif dan secara signifikan terhadap kinerja perusahaan.

4. Struktur modal, Current ratio, Laba perlembar saham / EPS berpengaruh secara simultan terhadap kinerja perusahaan yang berarti berpengaruh signifikan secara simultan terhadap kinerja perusahaan.

\section{Daftar Pustaka}

[1] Sindonews.11oktober2018,21.11. https://ekbis.sindonews.com/read/1349266/34/industri-manufakturdominasi-nilai-ekspor-nasional-hingga-72-1540473293.

[2] Amalia Dewi Rahmawati, (2015).” Pengaruh Ukuran Perusahaan, Probabilitas, Struktur Modal, Dan keputusan Investasi Terhadap Nilai Perusahaan". Vol. 23 No. 2 Juni 2015 : Universitas Brawijaya.

[3] Denice Pretorius, 2013.” The Effect Of Expensing Share-based Payments On Basic Earnings Per Share Of South African listed companies". Vol. 21 : University of Pretoria, Pretoria, South Africa.

[4] Eka Susilawati, (2014). "Pengaruh Rasio Likuiditas, Rasio Solvabilitas, Dan Rasio Probalitas Terhadap Earning Per Sahre". Jurnal Akuntansi. Vol.2 No. 1 Juni 2014 : Universitas Sarjanawiyata Tamansiswa.

[5] Hermuningsih,2013."Pengaruh Investment Opportunity Set, Struktur Modal, Pertumbuhan Perusahaan, Dan Return On Asset Terhadap Nilai Perusahaan". Vol. VIII No. 1, April 2015: UIN Syarif Hidayatullah Jakarta.

[6] Kadek Prawisanti Dira, (2014).” Pengaruh Struktur Modal, Likuiditas, Pertumbuhan Laba, Dan Ukuran ,Perusahaan Pada Kualitas Laba”. E-Jurnal Akuntansi Universitas Udayana 7.1 (2014) : Universitas Udayana (Unud), Bali, Indonesia.

[7] Kasih, 2014."Pengaruh Good Corporate Governance Dan Ukuran Perusahaan Terhadap Kinerja Perusahaan". Universitas Muhammadiyah Surakarta.

[8] Kostis Indounas, (2014)."The Antecedents Of Strategic Pricing And Its Effect On Company Performance In The Case Of Industrial Service Firms". Vol. 28 : Athens University of Economics and Business, Athens, Greece.

[9] Maladijan, 2014."Pengaruh Earning Per Share, Tingkat Pertumbuhan Perusahaan Dan Current Ratio Terhadap Kebijakan Dividen". Vol. 5, No. 11, 2016: Universitas Udayana, Bali, Indonesia.

[10] Nancy Bouranta, 2017." Identifying The Critical Determinants Of TQM And Their Impact On Company Performance: Evidence From The Hotel Industry Of Greece". Vol. 29 : University of Piraeus, Piraeus, Greece. 
[11] Ni Putu Ayu Pudak Sari, (2014)." Faktor -faktor Yang Mempengaruhi Struktur Modal Pada Perusahaan Non Keuangan Yang Terdaftar Di Bursa Efek Indonesia Tahun 2008-2012”. E-Jurnal Akuntansi Universitas Udayana 7.1 (2014) : Universitas Udayana (Unud), Bali, Indonesia.

[12] Octama, 2011. "Pengaruh Modal Intelektual dan Pengungkapannya Terhadap Nilai Perusahaan: Efek Intervening Kinerja Perusahaan”. VOL. 16 NO.2 JULI 2015 : Universitas Muhammadiyah Yogyakarta.

[13] Raden Rustan Hidayat, (2013). "Pengaruh Analisis Leverage Terhadap Kinerja Keaungan Perusahaan". Vol. 8 No 1 Fabruari 2014 : Universitas Brawijaya Malang.

[14] Rahman Rusdi Hamidy, (2015)." Pengaruh Struktur Modal Terhadap Nilai Perusahaan Dengan Profitabilitas Sebagai Variabel Intervening Pada Perusahaan Properti Dan Real Estate Di Bursa Efek Indonesia". E-Jurnal Ekonomi dan Bisnis Universitas Udayana 4.10 (2015) : Universitas Udayana (Unud), Bali, Indonesia.

[15] Redawati dkk, 2014."Pengaruh Struktur Modal Terhadap Kinerja Perusahaan”. Vol. 2, Nomor 1, Februari 2014 : Universitas Lambung Mangkurat Banjarmasin.

[16] Samuel Pramana Dwidjaja, 2017."Faktor-Faktor Yang Mempengaruhi Struktur Modal Dan Pengaruhnya Terhadap Kinerja Perusahaan Yang Terdaftar Di Bursa Efek Indonesia Periode 2011-2015". Vol.6 No.2 (2017): Universitas Surabaya.

[17] Santanu K. Ganguli, 2013." Capital Structure - Does Ownership Structure Matter? Theory And Indian Evidence". Vol. 30 : Institute of Management Technology - Ghaziabad, Ghaziabad, India.

[18] Simanjuntak, 2011:3.“ Pengaruh Komitmen Organisasi Terhadap Keberhasilan Penerapan Sistem Informasi Akuntansi Dan Dampaknya Pada Kinerja Perusahaan”. Unpas Bandung.

[19] Sirojodin dan Nazaruddin, 2014.’Pengaruh Modal Intelektual Dan Pengungkapannya Terhadap Nilai Perusahaan: Efek Intervening Kinerja Perusahaan". VOL. 16 NO.2 JULI 2015 : Universitas Muhammadiyah Yogyakarta.

[20] Sukma, 2013."Pengukuran Kinerja Perusahaan Dengan Menggunakan Metoda Balanced Scorecard". Vol. 13, No.1, Desember 2015 : UIN Sultan Syarif Kasim Riau.

[21] Tesfaye, 2014."Determinants of the adjustment speed of capital structure: Evidence from developing economies". Vol. 15 : University of the Witwatersrand, Johannesburg, South Africa.

[22] Wang dan Zhu, 2014."The Impact Of Capital Structure On Corporate Performance Based On Panel Threshold Model". Computer Modelling \& New Technologies 2014 : Hefei University of Technology Hefei Anhui, China.

[23] Yee Peng Chow, 2018." Macroeconomic Uncertainty, Corporate Governance And Corporate Capital Structure". Vol. 14 : Universiti Putra Malaysia, Serdang, Malaysia.

[24] Yunita Catelia Arisadi, (2013). “Pengaruh Ukuran Perusahaan, Umur Perusahaa, Current Ratio, Debt to Equity Ratio Dan Fixed Asset to Total Aset Ratio Terhadap Kinerja Keuangan Pada Perusahaan Manufaktur Di Bursa Efek Indonesia”. Vol. 11. No 4 2103. Universitas Brawijaya Malang. 